ACTA AGROBOTANICA

Vol. 61 (2): 141-146

2008

\title{
INFLUENCE OF HAND THINNING OF FLOWERS AND FRUITS ON YIELDING AND FRUIT QUALITY OF APPLES CULTIVAR SZAMPION
}

\author{
Stanisław Wociór \\ Department of Seed Production and Nurseries, University of Life Sciences in Lublin, Leszczyńskiego 58, 20-068 Lublin, Poland \\ e-mail: stanislaw.wocior@.up.lublin.pl
}

Received: 16.01 .2008

$\mathrm{Su} \mathrm{m} \mathrm{m}$ a r y

The thinning of flowers and fruit sets did not change the strength of tree growth in a significant way. Szampion cv. trees on rootstock A 2 grew better than on M.7. The trees of Szampion RENO cv. grew significantly worst. The thinning of flowers and fruit sets decreased the yield from a tree and the total yield from 1 ha of the studied biological material. Flower thinning slightly increased the mean commercial yield as compared to the control trees. Thinning of $50 \%$ of flowers at the stage of the pink bud and sets after the June fall decreased the number of fruits on the trees of Szampion cv. grafted on M.7. It was only in 2004 that the flower thinning treatment significantly increased the fruit weight. Flower thinning increased the percentage of fruits with a diameter of over $7 \mathrm{~cm}$ in the case of Szampion cv. trees grafted on M.7. This treatment considerably (in 2006 significantly) improved fruit colouring. A positive reaction to flower thinning was also observed in Szampion RENO trees. In the case of Szampion cv., which shows a tendency to excessive fruit setting and small fruits, it is better to apply flower thinning eliminating the excess of sets in the period of cell division in growing fruits than do it later, after the June fall. The inflorescence removal treatment requires much more time than thinning of fruit sets.

Key words: apple, rootstock, thinning, yielding, fruit quality

\section{INTRODUCTION}

In the conditions when the European Union market is saturated with apple fruits, the quality of apples offered becomes a very important issue (Makos z, 2007). The most commonly applied methods of improving the quality of fruit is to use manual or chemical thinning of flowers of fruit sets (B a s a k, 1993; Jones et al. 1997; Link and Blake, 1998; Basak and Jadczuk, 1999; Krzewińska et a1. 1999; Wieniarska et a1.2000; Basak et a 1. 2002; Tyburski et a 1.2006). A common view dominates in scientific literature and in practice that chemical thinning is largely unreliabile, while manual thinning is very time-consuming.
The purpose of the studies was to find out the effect of manual thinning of flowers and fruit sets on the size and quality of the yield of Szampion cv. apple trees, one of the most popular cultivars in production orchards.

\section{MATERIALS AND METHODS}

The experiment was established in 2004 on a production quarter of Szampion cv. planted on grey brown podzolic soil in 2000. The trees of this cultivar grafted on semi-dwarf $\mathrm{M} 7$ rootstock were planted at a spacing of $3.8 \times 1.7 \mathrm{~m}$ (about 1,550 trees per $1 \mathrm{ha}$ ) and on strongly growing A 2 rootstock at a spacing of 4 x 2 m (1,250 trees). In 2005 cv. Szampion RENO trees were included in the studies, grafted on M.7 rootstock and planted at a spacing of $4 \times 2 \mathrm{~m}$ at the same time as the above mentioned plants.

The experiment was set up in a scheme of random blocks in 5 repetitions. The repetitions were the plots where 3 trees grew on each. The following set of combinations was used for the studied material:

1. Szampion on M.7 - control

2. Szampion on M.7 - manually thinned every second fluorescence at the pink bud stage

3. Szampion on M.7 - manually thinned after the June fall - distorted and small sets were left, leaving the petioles

4. Szampion RENO on M.7 - control

5. Szampion RENO on M.7 - 50\% flowers removed like in combination 2

6. Szampion on A 2 - control

7. Szampion on A 2 - thinned after the June fall like in combination 3 .

The tree diameter at a height of $30 \mathrm{~cm}$ was measured in the experiment. The yield from each tree was weighed. Fruits picked up from particular trees were counted in combinations 1-3. During the harvest, 1 box of fruits from a repetition was taken for each 
combination. Those fruits were sorted out, estimating the proportion of fruits with a diameter of over $7 \mathrm{~cm}$ in the yield and the quantity of fruits with a pink blush covering more than $75 \%$ of the peel surface.

Based on these measurements, the cross-section area of the trunks was calculated as well as total and commercial yields from 1 ha of the orchard, the mean weight of fruits and the percentage of fruits with a diameter of over $7 \mathrm{~cm}$ and the colouring of over $75 \%$ of the peel area. Besides, measurements were made of the time of thinning and fruit gathering.
The results were statistically analyzed using variance analysis and Tukey's confidence intervals at the level of significance of $5 \%$.

\section{RESULTS AND DISCUSSION}

No significant effect of the thinning treatments was shown on the growth of Szampion cv. trees on two rootstocks and of cv. Szampion RENO.

Table 1

Influence of type of thinning and rootstock on the growth of apple trees cv. Szampion in 2004-2006.

\begin{tabular}{|c|c|c|c|c|c|c|c|c|}
\hline \multirow{3}{*}{ Combinations } & \multirow{2}{*}{\multicolumn{3}{|c|}{ Trunk cross section area in $\mathrm{cm}^{2}$}} & \multicolumn{5}{|c|}{ Time of thinning } \\
\hline & & & & \multicolumn{4}{|c|}{ for one tree in $\min$. } & \multirow{2}{*}{$\begin{array}{c}\text { for one ha } \\
\text { in } h\end{array}$} \\
\hline & 2004 & 2005 & 2006 & 2004 & 2005 & 2006 & $\bar{x}$ & \\
\hline Szampion on M.7 & $37.3 \mathrm{bc}$ & $47.3 \mathrm{ab}$ & $54.9 \mathrm{a}$ & 0 & 0 & 0 & 0 & 0 \\
\hline \multicolumn{9}{|l|}{ Control } \\
\hline Szampion on M.7 & $32.5 \mathrm{c}$ & $44.8 b$ & $51.7 \mathrm{a}$ & 17 & 20 & 25 & 21 & 542 \\
\hline \multicolumn{9}{|l|}{ Thinning of $50 \%$ of flowers } \\
\hline Szampion on M.7 & $34.0 \mathrm{c}$ & $43.0 \mathrm{~b}$ & $50.3 \mathrm{a}$ & 12 & 15 & 15 & 14 & 362 \\
\hline \multicolumn{9}{|l|}{ Thinning after June fall } \\
\hline Szampion RENO on M.7 & & $30.1 \mathrm{c}$ & $33.1 \mathrm{~b}$ & & & & & \\
\hline \multicolumn{9}{|l|}{ Control } \\
\hline Szampion RENO on M.7 Thinning of & & $30.0 \mathrm{c}$ & $32.1 b$ & & & & & \\
\hline \multicolumn{9}{|l|}{$50 \%$ of flowers } \\
\hline Szampion on A 2 & $43.0 \mathrm{a}$ & $52.8 \mathrm{a}$ & & & & & & \\
\hline \multicolumn{9}{|l|}{ Control } \\
\hline Szampion on A 2 & $40.7 \mathrm{ab}$ & $50.2 \mathrm{ab}$ & & & & & & \\
\hline Thinning after June fall & & & & & & & & \\
\hline
\end{tabular}

Means followed by the same letters do not differ significantly for $\mathrm{p}=0.05$

The trees grew worse on M.7 as compared to A 2 rootstock. In 2004 significant differences were shown between these rootstocks. The trees of cv. 'Szampion RENO' were characterized by the poorest growth as compared to the other combinations.
The thinning of one tree on a semi-dwarf rootstock M.7 lasted from 12 to 25 minutes. Less intensive thinning of sets after the June fall required less time. The thinning treatments required 362-542 man-hours per 1 ha. 
Table 2

Influence of type of thinning and rootstock on yielding of apples cv. Szampion in 2004-2006.

\begin{tabular}{|c|c|c|c|c|c|c|}
\hline \multirow{2}{*}{ Combinations } & \multicolumn{4}{|c|}{ Yield from tree in $\mathrm{kg}$} & \multicolumn{2}{|c|}{$\begin{array}{c}\text { Mean yield from one } \\
\text { ha in } t\end{array}$} \\
\hline & 2004 & 2005 & 2006 & $\bar{x}$ & Total & $\begin{array}{l}\text { Com- } \\
\text { mercial }\end{array}$ \\
\hline Szampion on M.7 & $46.5 \mathrm{a}$ & $47.5 b$ & $33.0 \mathrm{a}$ & 42.3 & 65 & 49 \\
\hline \multicolumn{7}{|l|}{ Control } \\
\hline Szampion on M.7 & $40.0 \mathrm{~b}$ & $39.8 \mathrm{~cd}$ & $29.1 \mathrm{ab}$ & 36.3 & 56 & 50 \\
\hline \multicolumn{7}{|l|}{ Thinning of $50 \%$ of flowers } \\
\hline Szampion on M.7 & $34.8 \mathrm{c}$ & $37.4 \mathrm{~d}$ & $30.0 \mathrm{a}$ & 34.1 & 53 & 33 \\
\hline \multicolumn{7}{|l|}{ Thinning after June fall } \\
\hline Szampion RENO on M.7 & & $42.8 \mathrm{c}$ & $29.9 \mathrm{ab}$ & 36.3 & 45 & 33 \\
\hline \multicolumn{7}{|l|}{ Control } \\
\hline Szampion RENO on M.7 & & $39.0 \mathrm{~cd}$ & $27.5 b$ & 33.2 & 41 & 34 \\
\hline \multicolumn{7}{|l|}{ Thinning of $50 \%$ of flowers } \\
\hline Szampion on A 2 & $48.4 \mathrm{a}$ & $57.2 \mathrm{a}$ & & 52.8 & 66 & 45 \\
\hline \multicolumn{7}{|l|}{ Control } \\
\hline Szampion on A 2 & $40.6 \mathrm{~b}$ & $41.9 \mathrm{~cd}$ & & 41.2 & 51 & 43 \\
\hline Thinning after June fall & & & & & & \\
\hline
\end{tabular}

Explanations as in table 1

In the case of the control combinations, the highest yield from a tree was obtained from Szampion on A 2 only in 2005. The differences between the rootstocks and between Szampion RENO and Szampion proved to be significant. Similar tendencies were observed in the other years of the study, but the differences between the studied biological material turned out to be insignificant.

The present observations confirm the fact known in literature that the strength of tree growth and its yielding are mostly determined by biological elements: the rootstock and the cultivar (Bielicki et al. 1999; Wociór et al. 2001).

Flower thinning significantly decreased the yielding of cv. Szampion on M.7 in the first two years of the study. A similar tendency was observed in Szampion in 2006 and in Szampion RENO in both study years, but the differences between the combinations were insignificant.

Set thinning in the years 2004 and 2005 significantly decreased the yield of cv. Szampion on both rootstocks. In 2006 the differences between the control trees and those on which sets were thinned were insignificant.

The present results confirm those which were obtained in experiments of a number of authors (B a s a k, 1993; Jones et al. 1997; Link and Blanke, 1998; Wieniarska et al. 2000; Kapłan and Wociór, 2005; Tyburski et al.2006), pointing to the fact that flower set thinning decreases the total yield. The degree of yield reduction depended on thinning intensity as well as the manner and date of the treatment.

Flower thinning increased the commercial yield from 1 ha by about 1 ton for the cultivars of Szampion and Szampion RENO. Irrespective of the rootstock, fruit set thinning slightly decreased the commercial yield as compared to the control combination.

Wieniarska et al.(2000) and Szot (2007) report that - depending on the manner and date of thinning - an increase of the commercial yield of Szampion $\mathrm{cv}$. was obtained. Earlier thinning usually gave better results. A similar regularity was observed in the present studies. 
Table 3

Influence of thinning on the number of fruits and the fruit weight in apples cv. Szampion in 2004-2006.

\begin{tabular}{lrrrrrrrr}
\hline & \multicolumn{3}{c}{ Number of fruits on tree } & & \multicolumn{2}{c}{ Fruit weight in g } \\
\cline { 2 - 8 } & 2004 & 2005 & 2006 & $\bar{x}$ & 2004 & 2005 & 2006 & $\bar{x}$ \\
\hline $\begin{array}{l}\text { Szampion on M.7 } \\
\text { Control }\end{array}$ & $297.3 \mathrm{a}$ & $239 \mathrm{a}$ & $193.4 \mathrm{a}$ & 243 & $135.0 \mathrm{~b}$ & $179 \mathrm{a}$ & $170.6 \mathrm{a}$ & 161 \\
$\begin{array}{l}\text { Szampion on M.7 } \\
\text { Thinning of 50\% of flowers }\end{array}$ & $264.7 \mathrm{a}$ & $210 \mathrm{~b}$ & $183.0 \mathrm{a}$ & 219 & $176.1 \mathrm{a}$ & $189 \mathrm{a}$ & $159.0 \mathrm{a}$ & 175 \\
$\begin{array}{l}\text { Szampion on M.7 } \\
\text { Thinning after June fall }\end{array}$ & $253.0 \mathrm{a}$ & $216 \mathrm{~b}$ & $211.4 \mathrm{a}$ & 227 & $137.5 \mathrm{~b}$ & $173 \mathrm{a}$ & $170.2 \mathrm{a}$ & 160 \\
\hline
\end{tabular}

Explanations as in table 1

On average, in the course of 3 years, the thinning of flowers and fruit sets decreased the number of fruits of Szampion cv. on the trees grafted on M.7. The differences between the control combination and the thinned trees were significant only in 2005.

Flower thinning significantly increased the fruit weight of Szampion cv. only in 2004. It deserves mentioning that in 2004, in the control combination and after thinning, fruits of much smaller weight were obtained as compared to the previous years.
Numerous authors (Krzewińska et al. 1999; Czynczyk et al. 2001; Kapłan and Wociór, 2005; S z ot, 2007) suggest leaving only a definite number of sets in the period of manual thinning so as to ensure a satisfactory yield of very good quality. The present studies point out that in the case of the Szampion cv. trees grafted on semi-dwarf rootstock M.7 this number should not exceed 200. This problem requires further studies.

Table 4

Influence of type of thinning and rootstock on fruit quality in apples cv. Szampion in 2004-2006.

\begin{tabular}{|c|c|c|c|c|c|c|c|}
\hline & \multicolumn{4}{|c|}{$\begin{array}{l}\text { Percentage of fruits with a diameter of over } \\
\qquad 7 \mathrm{~cm}\end{array}$} & \multicolumn{3}{|c|}{$\begin{array}{l}\text { Percentage of fruits with coloration on } \\
\text { over } 75 \% \text { of fruit surface }\end{array}$} \\
\hline & 2004 & 2005 & 2006 & $\bar{x}$ & 2004 & 2005 & 2006 \\
\hline $\begin{array}{l}\text { Szampion on M.7 } \\
\text { Control }\end{array}$ & $70.4 b$ & $82.0 \mathrm{ab}$ & 73.9ab & 75 & $26.8 \mathrm{a}$ & $83.0 \mathrm{a}$ & $10.7 \mathrm{~d}$ \\
\hline $\begin{array}{l}\text { Szampion on M.7 } \\
\text { Thinning of } 50 \% \text { of flowers }\end{array}$ & $94.4 \mathrm{a}$ & $92.0 \mathrm{a}$ & $81.0 \mathrm{a}$ & 89 & $37.0 \mathrm{a}$ & $90.0 \mathrm{a}$ & $22.6 \mathrm{c}$ \\
\hline $\begin{array}{l}\text { Szampion on M.7 } \\
\text { Thinning after June fall }\end{array}$ & $69.8 \mathrm{~b}$ & $49.3 \mathrm{~d}$ & $71.1 \mathrm{~b}$ & 63 & $15.0 \mathrm{a}$ & $73.0 \mathrm{~b}$ & $14.0 \mathrm{~d}$ \\
\hline $\begin{array}{l}\text { Szampion RENO on M.7 } \\
\text { Control }\end{array}$ & & $82.0 \mathrm{ab}$ & $66.3 \mathrm{c}$ & 74 & & $83.0 \mathrm{a}$ & $39.4 b$ \\
\hline $\begin{array}{l}\text { Szampion RENO on M.7 } \\
\text { Thinning of } 50 \% \text { of flowers }\end{array}$ & & $92.0 \mathrm{a}$ & $67.6 \mathrm{bc}$ & 80 & & $90.0 \mathrm{a}$ & $73.7 \mathrm{a}$ \\
\hline $\begin{array}{l}\text { Szampion on A } 2 \\
\text { Control }\end{array}$ & $70.1 b$ & $68.6 \mathrm{c}$ & & 69 & $17.0 \mathrm{a}$ & $52.0 \mathrm{c}$ & \\
\hline $\begin{array}{l}\text { Szampion on A } 2 \\
\text { Thinning after June fall }\end{array}$ & $89.8 \mathrm{a}$ & $78.7 b c$ & & 84 & $18.0 \mathrm{a}$ & $51.0 \mathrm{c}$ & \\
\hline
\end{tabular}

Explanations as in table 1 
In the case of the Szampion and Szampion RENO cultivars, the studies found out a positive effect of flower thinning on the percentage of fruits with a diameter of over $7 \mathrm{~cm}$ in the yield. Significant differences, in comparison to the control combination, were observed only for Szampion cv. in 2004.

Removing distorted and small sets after the June fall did not improve the percentage of fruits with a diameter of over $7 \mathrm{~cm}$. A similar effect was obtained in earlier studies (Kapłan and Wociór, 2005) conducted on Szampion cv. trees grafted on M.26 and P 60 when thinning was not intensive.

A small or no effect of set thinning after the June fall on the commercial yield of Szampion cv. was observed in the most recent studies by S z o t (2007).

Sets thinning did not significantly affect the colouring of Szampion cv. fruits on either rootstock in the years 2004 and 2006. In 2005 this treatment significantly decreased the percentage of very well coloured fruits of Szampion cv. on M.7, and it did not change this property in the trees grafted on A 2.

Flower thinning had a positive effect on the percentage of very well coloured fruits of 'Szampion' and Szampion RENO cultivars in each year of the study, and only in 2006 the differences were significant compared to the control combination.

In 2005 much better fruit colouring was found out in all combinations than in the other years. The positive effect of early thinning on fruit colouring is also observed by other authors (Wieniarska et a 1. 2000; Krzewińska et al.2002).

\section{CONCLUSIONS}

1. The thinning of flowers and fruit sets did not change the strength of tree growth in a significant way. The Szampion cv. trees on rootstock A 2 grew better than on M.7. The trees of Szampion RENO cv. grew significantly worst.

2. The thinning of flowers and fruit sets decreased the yield from a tree and the total yield from 1 ha of the studied biological material. Flower thinning slightly increased the mean commercial yield as compared to the control trees.

3. Thinning of $50 \%$ of flowers at the stage of the pink bud and sets after the June fall decreased the number of fruits on the trees of Szampion cv. grafted on M.7. It was only in 2004 that the flower thinning treatment significantly increased the fruit weight. Fruit set thinning after the June fall did not change the fruit weight in any significant way as compared to the control combination.

4. In the case of Szampion cv. trees grafted on M.7, flower thinning increased the percentage of fruits with a diameter of over $7 \mathrm{~cm}$. This treatment con- siderably (in 2006 significantly) improved fruit colouring. A positive reaction to flower thinning was also observed in the Szampion RENO trees.

5. The effect of fruit set thinning on fruit quality was related to the rootstock and it varied in particular years. The thinning of sets of Szampion cv. on M.7 after the June fall in the years 2004 and 2006 only slightly affected the percentage of fruits with a diameter of over $7 \mathrm{~cm}$ and fruit colouring. In 2005 the studies showed an incomprehensible fall in the percentage for both these features as compared to the control combination. The Szampion cv. trees grafted on A 2 increased the percentage of frutis with a diameter of over $7 \mathrm{~cm}$ after fruit set thinning, but did not improve the colouring.

6. Considerable differences in colouring between the study years point out that the weather determined the quantity of very well coloured fruits to a greater degree that thinning treatments.

7. In the case of Szampion cv., which shows a tendency to excessive fruit setting and small fruits, it is better to apply flower thinning eliminating the excess of sets in the period of cell division in growing fruits than do it later, after the June fall. The inflorescence removal treatment requires much more time than thinning of fruit sets.

\section{REFERENCES}

B as ak A. 1993. Search far safer technologics od apple fruitlets thinning. Acta Hort. 329: 240-242.

Basak A., Jadczuk E. 1999. Wyniki badań z zastosowaniem Promalinu do przerzedzania zawiązków jabłoni odmian Szampion i Elstar. / Studies on using of Promalin for fruit set thinning of apple cultivars Szampion and Elstar. Zesz. Nauk. AR w Krakowie, 66: 175-178.

Basak A., Wieniarska J., Jadczuk E. 2002. Wyniki badań z zastosowaniem preparatów Promalin i Regules w sadach jabłoniowych. / Studies on using of Promalin and Regules in apple orchards. Zesz. Nauk. Inst. Sadow. Kwiac. Skiern. 10: 19-28.

Bielicki P., Czynczyk A., Bartosiewicz B. 1999. Effects of new Polish rootstocks and M.9 clones on growth, cropping and fruit quality of three apple cultivars. Proc. of Int. Seminar Warsaw: 15-16.

Czynczyk A., Treder W., Keller J., Kiełkiew i c z M. 2001. Wpływ liczby zawiązków na drzewach odmiany 'Lobo' na M.9 na jakość owoców i przemienność owocowania. / Influence of the number of fruit sets on 'Lobo' cv. trees on M.9 on fruit quality. Zesz. Nauk. Inst. Sadow. Kwiac. Skiern. 10: 161-166.

Jones K., Bound A.A., Gillard P., Oakford M.J. 1997. Working model of apple thinning. Acta Hort. 463: 475-480.

Kapłan M., Wociór S. 2005. Wpływ ręcznego przerzedzania zawiązków jabłoni Szampion na jakość plonu. / 
Influence of hand thinning of fruit sets on fruit quality of cv. 'Szampion'. Sad. Nowoczesny, 7: 18-19.

Krzewińska D., Basak A., Mika A. 1999. Wpływ liczby zawiązków owocowych na drzewie na plon i jakość jabłek w czasie zbioru i po przechowywaniu. / Influence of number of fruit sets on a tree on yielding and fruit quality. Zesz. Nauk. AR w Krakowie, 66: 179184.

Krzewińska D., Basak A., Mika A.Michalska B. 2002. Wpływ terminu i intensywności przerzedzania zawiązków owocowych na rozkład jabłek w klasach wielkości i wybarwienia. / Influence of date and intensity of fruit set thinning on the size and colouring of apples. Zesz. Nauk. Inst. Sadow. Kwiac. Skiern. 10: 89-99.

Link M., Blanke M. 1998. Effect of thinning in a long term trial with six apple cultivars on yield and fruit size. Acta Hort. 466: 59-64.

Makosz E. 2007. Szanse rozwoju polskiego sadownictwa. / Development opportunities Polish orcharding). Plantpress Kraków 2007.

Szot I. 2007. Wpływ intensywności ręcznego przerzedzania zawiązków na wybrane cechy jakościowe jabłek odmiany 'Szampion'. / Influence of intensity of hand thinning of sets on fruit quality of cv. Szampion. Roczniki AR w Poznaniu, Ogrodnictwo, 41: 395-402.

Tyburski M.S., Waźbińska J., Płoszaj B. 2006. Wpływ przerzedzania zawiązków owocowych jabłoni na zawiązywanie owoców i plon oraz niektóre cechy jakościowe jabłek Cz. I, II, III. / Influence of fruit set thinning on yielding and fruit quality of apple trees. XLIV Ogólnop. Nauk. Konf. Sad. Inst. Sadow. Kwiac. Skiern.: 126-132.

Wieniarska J., Basak A., Szember E., Murawska D. 2000. Ocena plonowania i jakości owoców odmian Szampion i Jonagold po przerzedzaniu zawiązków owocowych. / Studies of yielding and fruit quality after fruit set thinning. Zesz. Nauk. AR w Krakowie, 364: 287-291.

Wociór S., Baryła P., Palonka S., Wójcik I., Kapłan M. 2001. Wpływ podkładek na plonowanie i jakość owoców trzech odmian jabłoni. / Influence of rootstocks on yielding and fruit quality of three apple cultivars). Zesz. Nauk. Inst. Sadow. Kwiac. Skiern.: 77-82.

\section{Wpływ ręcznego przerzedzania kwiatów i zawiązków na plonowanie i jakość owoców odmiany Szampion}

\author{
Streszczenie
}

Przerzedzanie kwiatów i zawiązków nie zmieniało istotnie siły wzrostu drzew. Drzewa odmiany 'Szampion' na podkładce A 2 rosły silniej niż na M.7. Istotnie najsłabiej rosły drzewa odmiany Szampion RENO. Przerzedzanie kwiatów i zawiązków zmniejszało plon z drzewa i sumaryczny plon z hektara badanego materiału biologicznego. Przerzedzanie kwiatów zwiększało nieznacznie średni plon handlowy w porównaniu do drzew kontrolnych. Przerzedzanie $50 \%$ kwiatów w fazie różowego pąka i zawiązków po opadzie czerwcowym zmniejszało liczbę owoców na drzewach odmiany Szampion okulizowanych na M.7. Tylko w 2004 roku zabieg przerzedzania kwiatów istotnie zwiększał masę owocu. Przerzedzanie kwiatów zwiększało procent owoców o średnicy powyżej $7 \mathrm{~cm}$ w przypadku drzew odmiany Szampion okulizowanych na M.7. Zabieg ten poprawiał znacznie (w 2006 roku istotnie) wybarwienie owoców. U drzew odmiany Szampion RENO stwierdzono także pozytywną reakcję na przerzedzanie kwiatów. W przypadku odmiany Szampion wykazującej tendencję do nadmiernego zawiązywania i drobnienia owoców bardziej korzystne jest stosowanie przerzedzania kwiatów eliminujące nadmiar zawiązków w okresie podziału komórek w rosnących owocach niż późne przerzedzanie zawiązków po opadzie czerwcowym. Zabieg usuwania kwiatostanów wymaga większego nakładu czasu pracy niż przerzedzanie zawiązków. 